DOI: $10.35757 /$ SM.2018.71.1.10

HISTORIA I POLITYKA

ГРИГОРІЙ ПЕРЕПЕЛИЦЯ (GRIGORIJ PEREРЕLICA)

Київський національний університет ім. Тараса Шевченка, Україна

(Taras Shevchenko National University of Kyiv, Ukraine)

\title{
Україна та Польща: \\ 25 років посткомуністичного транзиту (порівняльний аналіз)
}

\section{Ukraine and Poland: 25 Years of Post-Communist Transit (Comparative Analysis)}

The key trend in the development of central Europe and the Soviet Union in the late 20th century was the destruction of the communist system based on the Communist Party's monopoly on power, communist ideology, an authoritarian regime and a planned administrative economy. Like Poland, Ukraine underwent these transformations for 25 years. However, the course and results of these transformations were fundamentally different in Ukraine. These differences were due to various historical, political, social, economic and spiritual factors, different forces of influence on these transformational processes, as well as external and internal factors.

The agenda for social change in Ukraine is much more complicated than in Poland, where the process of establishing democracy was primarily due to an external factor. The process of joining NATO and the European Union allowed Poland to compensate for the lack of a consolidated elite and the mass support from broad social strata. The very idea of membership of NATO and the EU has become the subject of consolidation of these elites.

Ukraine has lost the possibility of such external support for democratic processes, at least in a certain historical period. Ukraine needs to take account of these historical, mental and geopolitical specifics. Thus, the historical priority tasks faced by Ukraine are: de-Sovietisation, decolonisation, de-Russification, democratisation, de-oligarchization, Europeanisation and the formation of a powerful intellectual opposition, a consensus of the elites on the model of the future of Ukraine, and the development of a clear strategy for social change. Obviously, Ukraine itself should undergo the second round of transformations from authoritarianism and kleptocracy to democracy if it wants to remain an independent sovereign state and be preserved as a full Ukrainian nation.

Keywords: post-communist transit, de-Sovietisation, decolonisation, de-Russification, authoritarianism, kleptocracy, democratisation, de-oligarchization, Europeanisation, opposition, consensus of elites. 
Ключовою тенденцією розвитку країн Центральної Європи та Радянського Союзу (СРСР) наприкінці ХХ століття була руйнація комуністичної системи, що спиралася на монополію комуністичної партії на владу, комуністичну ідеологію, авторитарний режим та планово-адміністративну економіку. Очевидно, що перед країнами колишнього комуністичного блоку після його розвалу постали спільні завдання, які полягали у демонтажі політичної комуністичної системи: відмові від комуністичної ідеології, переході від тоталітаризму до демократії, побудові ринкової економіки на руїнах колишньої планово-адміністративної системи.

Протягом двадцятип'ятирічного періоду як Польща, так Україна здійснили ці перетворення. Проте, їх шляхи, глибина та результати виявилися принципово відмінними. Відмінності ці були обумовлені різними історичними, політичними, соціальними, економічними та духовними чинниками, різною силою впливу на ці трансформаційні процеси як зовнішніх, та і внутрішніх чинників. Головний водорозділ в цих відмінностях полягає в тому, що Польща, на відміну від України, завжди була частиною політичної та геополітичної Свропи. Ніхто не піддавав сумніву іiі приналежність до європейської цивілізації, європейської культурної спільноти та європейської історії. Приналежність Польщі до комуністичного табору тлумачилась як наслідок радянської окупації в результаті встановлення Ялтинсько-Потсдамської системи в Свропі. Руйнація цієї системи внаслідок закінчення «холодної війни» закономірно поставила на порядок денний європейської політики виведення радянських військ з Польщі та повернення її в Свропу шляхом приєднання до Північноатлантичного альянсу (НАТО) та Європейського Союзу ( $С \mathrm{C})$.

Україна була в Свропі тільки географічно. Отже, вона не могла розглядатись частиною політичної Європи і, тим більше, частиною європейської цивілізації тому, що перебувала в складі СРСР. Відтак, ті критерії, за якими Захід підходив до визначення долі Польщі та країн Центральної Європи, не могли бути застосовані до України. Вона не вважалась окупованою радянськими військами і не могла розраховувати на включення до європейської та євроатлантичної спільноти. Наслідки розпаду Ялтинсько-Потсдамської системи стосувалися хіба що країн Балтії, які вважалися окупованими радянськими військами в результаті підписання пакту Рібентропа - Молотова у 1939 році. Властиво, ці три прибалтійські країни, колишні республіки СРСР, і були включені в НАТО та СС. Таким чином, якщо домінуючий вплив на внутрішні процеси та зовнішню політику країн Балтії та Центральної Європи чинили ЄС, НАТО та 
США, то на пострадянському просторі такий зовнішній вплив здійснює Росія. Якщо вплив Заходу на Польщу був спрямований на демократичні перетворення та економічні реформи, то вплив російського чинника на Україну мав зворотній характер.

Інший вимір відмінностей - державотворчі та націотворчі процеси в Польщі та Україні. Ці процеси в історичному контексті пов'язані з постімперським та постколоніальним транзитом. Польща ще задовго до початку $\mathrm{XX}$ століття сформувалася як повноцінна європейська нація, яка виплекала власну національну еліту і мала великий досвід державотворення. Україна, більша частина якої знаходилася в складі Російської імперії, як і інші національні окраїни Росії, не мала такої можливості. Тож Польща, попри те, що була приєднана до комуністичного табору в результаті радянської окупації, зберегла свою державність, хоча ії суверенітет був обмежений Радянським Союзом. У той же час, польська комуністична еліта не відмовилась від своєї національної ідентичності, а правляча Польська об’єднана робітнича партія (ПОРП) за своєю спрямованістю мала націонал-комуністичний характер, хоча при цьому й сповідувала принципи інтернаціоналізму.

Комуністична партія Радянського Союзу теж сповідувала принцип інтернаціоналізму у своій внутрішній та зовнішній політиці, проте в реальності іiі зусилля були спрямовані проти будь-яких національних проявів в її національних осередках. Саме тому Комуністична партія України проводила антинаціональну політику, намагаючись перетворити Україну в таку соціальну спільноту як «радянський народ» на основі радянськоросійської ідентичності.

Отже, складність та відмінність трансформаційних процесів в Україні після розпаду радянської імперії та комуністичної системи полягала в тому, що перед нею в один і той же історичний період постало одразу чотири історичних завдання: створення власної незалежної держави, подолання колоніальної спадщини та формування української нації, проведення ринкових економічних реформ та встановлення демократичного політичного режиму. На відміну від Польщі Україна не мала значного досвіду державного будівництва та формування власної національної еліти. Відтак, виходячи із зазначених історичних передумов, слід констатувати, що в Україні трансформаційні процеси, пов'язані з переходом від авторитаризму до демократії та ринкової економіки, мають набагато складніший і суперечливіший характер, ніж ті, що мали місце в Польщі.

Ще одну відмінність сучасних трансформацій в Україні та Польщі можна помітити в тому, які цінності були покладені в основу цього 
двадцятип'ятирічного періоду системних змін. Рушійною силою трансформаційних перетворень в Україні та Польщі були різні мотивації. Як зазначає відомий російський політолог Андрій Рябов: «В країнах Центрально-Східної Свропи (ЦСЄ) революція цінностей відбулася ще до того, як політичні антикомуністичні революції 1989 року знищили комуністичний лад» ${ }^{1}$. Що стосується України, то очевидно, ніякої революції цінностей в кінці восьмидесятих років, усупереч поширеній думці, тут не відбулося.

Революція в Україні, як і перетворення на пострадянському простоpi у дев'яності роки, а відтак і отримання державного суверенітету, базувалися не на цінностях, а на патерналістських настроях суспільства та номенклатурних інтересах. У 1991 році на референдумі про державний суверенітет населення України голосувало виходячи суто з матеріальних, патерналістських мотивів, розраховуючи на покращення матеріальних умов життя та підвищення добробуту в умовах незалежності. Демократія, гасла якої експлуатуються до цього часу в Україні усіма без винятку політичними партіями, сприймається більшістю суспільства виключно як інструмент підвищення добробуту пересічних громадян. Рівним чином, як і європейський вибір України підтримується громадянами країни в очікуванні отримати матеріальну допомогу від $Є С$ та покращити своє матеріальне становище.

Домінування в українському суспільстві соціального популізму та патерналістських настроїв значно ускладнює формування в країні демократичного режиму і є досить сприятливою умовою для відтворення авторитаризму. Саме такий патерналістський підхід обумовлював стремління частини мешканців Донбасу та Криму повернути Україну знову в лоно Росії як метрополії, з надією отримати дешевий газ та "покращення життя вже сьогодні”.

Інструментальний характер цих демократичних перетворень був необхідним насамперед самій комуністичній номенклатурі, яка в умовах неефективності комуністичної системи прагнула отримати у приватну власність економічні і природні ресурси країни та власність на політичну владу. Державний суверенітет, як і поняття нації, не були цінністю для української партійної номенклатури. Втілення ідеї державного суверенітету України місцева номенклатура розглядала як інструмент

1 A. Râbov, Promežutočnye itogi i nekotorye osobennosti postsovetskih transformacij, http://polit.ru/article/2010/08/12/riabov (dostup: 5.05.2018). 
привласнення влади та економічних ресурсів, розміщених на її території незалежно від союзного керівництва в Москві. Відтак, якщо трансформаційні процеси в Польщі можна вважати революцією демократичних цінностей, то в Україні у 1991 році відбулася номенклатурна революція. Колишня комуністична номенклатура, яка закріпила свою владу в Україні в результаті такої революції, з самого початку не ставила перед собою завдання розбудови української держави чи консолідованої нації, чи формування консолідованої демократії. Головним завданням для неї було і залишається привласнення економічних ресурсів та інститутів державної влади в країні.

Саме тому головним для цієї влади в Україні у зовнішньополітичному вимірі у дев'яності роки стало гасло «Подалі від Росії». У концентрованому вигляді це гасло виписано у змісті книги президента Л. Кучми «Україна - не Росія»². В той же час для Польщі та більшості країн Центрально-Східної Свропи головним гаслом трансформаційних перетворень було гасло «Повернення в Свропу». Таким чином, євроатлантична інтеграція розглядалась країнами Центральної Європи як шлях повернення в Свропу, який дає можливість:

- звільнитись від радянської окупації;

- назавжди вийти з-під влади Росії;

- відтворити західну модель суспільства, яка існувала в цих країнах до комуністичного режиму, розглядаючи ії як найкоротший і найшвидший шлях до демократії і процвітання.

Для провладної еліти України «повернення в Європу» не стояло на порядку денному, а можливості та завдання, які при цьому мали бути вирішеними, не видавались їй актуальними. Влада та суспільство в Україні не розглядали радянські війська як окупаційні. Україна їх просто націоналізувала. Більше того, вона навіть закріпила російську військову присутність на своїй території на двадцять років і пролонгувала перебування Чорноморського флоту РФ на території України ще на 25 років до 2042 року, тим самим посиливши вплив та залежність від Росії

Отже, повернення в Європу і пов'язані з цим рухом можливості звільнення від радянської окупації, зменшення впливу Росії, ствердження державного суверенітету, демократії та процвітання не стало суттєвою

2 L. Kuczma, Ukraina to nie Rosja, przeł. Ê. Redlih, Platan, Kraków 2004.

3 Ugoda miž Ukraïnoû ta Rosìjs'koû Federaciêû z pytan' perebuvannâ Čornomors'kogo flotu Rosìjs'koï Federaciï na teritoriï Ukraïni (ukr/ros), http://zakon5.rada.gov.ua/laws/ show/643_359 (dostup: 5.05.2018). 
мотивацією в прискоренні трансформаційних процесів для влади та суспільства в Україні, порівняно з Польщею.

У такому разі трансформаційні процеси в Україні слід радше порівнювати не з Польщею, а з країнами що розвиваються, яким властивий постколоніальний транзит. Дійсно, Україна досить тривалий історичний період була вмонтована в імперсько-колоніальну модель Російської імперії і Радянського Союзу. Таким чином, за 25 років Україна не змогла подолати основні проблеми і розв'язати головні завдання постколоніального перехідного періоду. Брак у керівників держави політичної волі до проведення радикальних економічних реформ призвів до того, що в країні створилося сприятливе середовище для відтворення колоніальної залежності у формі неоколоніалізму4. Тільки сьогодні, під впливом російсько-української війни, відбувається руйнація такої моделі. На цій підставі подолання неоколоніалізму можна було б вважати головним мотивом для прискорення трансформаційних процесів у напрямку формування соборної української нації, єдиної і сильної української держави та європейської інтеграції. Проте, парадокс полягає в тому, що українці не вважають себе колонізованим народом яка полягала в тому, що значна частина соціуму, що мешкає в східних та південно-східних регіонах України, тяжіла до «русского мира», ідентифікуючи себе не з європейським, а з російським чи євразійським цивілізаційним простором. У кінцевому рахунку це спровокувало воєнну окупацію Криму і частини Донбасу Росією в результаті російської агресії проти України.

Рудименти такої суспільної свідомості обумовлені не тільки колоніальним минулим України, але й формуванням протягом радянської доби радянського психотипу поведінки людей, яких називають homo sovieticus. Радянські стереотипи поведінки є досить сталими для всього пострадянського простору. Суспільство, яке мислить подібними стереотипами, є надзвичайно пасивним і патерналістським. Отже соціум, який складається з таких пострадянських людей, не може бути опорою для впровадження економічних реформ і демократії в країні, рівною мірою як і для європейської інтеграції, оскільки він не поділяє європейські демократичні цінності.

4 O. Soskìn, Neokolonìal'na zaležnìst' Ukraïni vìd Rosiï: oznaki ta nebezpeka, http:// national.org.ua/library/neokolonialna.html (dostup: 5.05.2018).

5 S. Grabovs'kij, ,, Mi ukraïns 'kij narod: nacional'no-etnična mozaïka”. Etnonacional'nij portret Ukrä̈ni, www.radiosvoboda.org/a/909004.html (dostup: 5.05.2018). 
Відмінності посткомуністичного транзиту в Польщі та Україні обумовлені також внутрішніми політичними та соціокультурними чинниками. Найбільш суттєвим із цих чинників $є$ породжений системою колоніальних відносин панівний політичний клас в Україні. «Замість продуктивної національної буржуазії у нас функціонує сурогат компрадорської, космополітичної. Основою цього протобуржуазного ембріону є два сегменти: комуністично-комсомольська номенклатура і кримінальні угруповання, що представляють нині симбіоз. А замість високоорганізованої системи високоліквідного національного приватного капіталу в Україні переважає кланово-номенклатурний, державно-монополістичний, уражений метастазами корупції і хабарництва» ${ }^{6}$.

Наявність такого правлячого класу характерна для всіх посткомуністичних країн. В польській соціології така правляча група отримала назву «трансфер-класу». Російський політолог Андрій Рябов відносить до цієї групи класи, що вийшли з антикомуністичної революції, але при цьому вони бажають, щоб цей перехідний стан тривав як можна довше. Трансфер-класи представлені, насамперед, високо ресурсними групами, пов'язаними з експлуатацією державної власності, перерозподілом власності й бюджетних потоків, з певними традиціями управління й владних відносин, які були притаманні радянській номенклатурній системі.

Основною економічною рисою політичних режимів, які встановлюються трансфер-класами $є$ спосіб привласнення влади і власності. Його головною сутністю $є$ перерозподіл ресурсів і захоплення контролю над джерелами ренти. В якості джерела такої ренти в одному випадку виступає адміністративний ресурс та державні послуги, в другому - земля та природні ресурси, в третьому - одне і друге. «Постійна боротьба за переділ ресурсів призведе до хронічної слабкості й мінливості політичних і соціальних інститутів. Конкуруючі групи не зацікавлені у встановленні правил і процедур - вони вважають за краще грати з правилами ніж грати за правилами. В результаті інститут власності, покликаний відігравати провідну роль у забезпеченні правових основ ринкової економіки, здобуває умовний характер - як при феодалізмі» 7 .

В умовах пострадянського капіталізму корупція стає системним фактором такої системи відносин. «Приватизація адміністративного ресурсу

6 O. Soskìn, Neokolonial'na zaležnìst' Ukraïni vìd Rosï: oznaki ta nebezpeka, http:// national.org.ua/library/neokolonialna.html (dostup: 5.05.2018).

7 A. Râbov, Promežutočnye itogi i nekotorye osobennosti... 
чиновництвом при відсутності механізмів підзвітності і громадського контролю формує корупційне середовище. Державні послуги повсюдно стають об'єктом купівлі-продажу, а державна служба - інструментом стягування ренти й поборів з населення і бізнесу, а також створення сприятливого середовища для опікуваних чиновниками підприємницьких структур» ${ }^{8}$.

Ексклюзивний доступ до отримання адміністративної, бюджетної та природної ренти стає можливим при умові власності на політичну владу. Саме тому ці класи називають олігархією. Їх спільне прагнення полягає в тому, щоб зберегти ексклюзивний доступ до влади і ресурсів, а також законсервувати перехідний стан суспільства на якомога довший період. Держава та державний суверенітет для олігархії не $є$ цінністю. Ці категорії в інтересах олігархії мають виключно економічний вимір. Виходячи 3 цього, вона не зацікавлена в процесі державотворення та сильній державі. Навпаки, вона намагається зробити державні інститути надзвичайно слабкими, звести їх функції до механізму отримання ренти, тобто рентної держави. Не зацікавлена олігархія і в інститутах громадянського суспільства, які можуть складати політичну конкуренцію владній олігархії. Слабкість громадських та державних інститутів унеможливлює реалізацію довготермінових національних стратегій. Слабкі інститути змушують різні елітні групи орієнтуватися на реалізацію короткотермінових, головним чином, корпоративних та групових цілей. Отже, такі системи абсолютно нездатні для здійснення політики реформ та національного розвитку. У них, як констатує А. Рябов, фактично не діє на практиці інститут політичної відповідальності. «Як правило, всі рішення приймаються на самій верхівці, але відповідальність за погані рішення президенти і прем'єри спускають вниз, на інших суб'єктів політики»'.

Однією з суттєвих рис авторитарних режимів в країнах пострадянського капіталізму, до яких безумовно належить і Україна, $\epsilon$ персоніфікація влади та клієнтилізація владних відносин. Цього потребує сама рентна економіка та ексклюзивний характер доступу до ренти на владу, яка сконцентрована в руках дуже вузького кола політичних акторів. Сенс іï діяльності зводиться до збереження такого ексклюзивного монопольного доступу до влади, або до захоплення нових ресурсів. Відтак, ці правлячі еліти апріорі не можуть бути носіями довготермінових стратегій

8 Ibidem.

9 Ibidem. 
розвитку. Значною мірою, формування олігархічного ладу та клептократичного політичного режиму в Україні стало можливим за умови відсутності націєтворчого процесу, який би призвів до створення соборної української нації - носія національних інтересів, джерела національної еліти - й утворення на цій основі сталої української державності. Український дослідник Андрій Холявка з цього приводу констатує: «Політичну, економічну і культурну владу в незалежній Україні захопила колишня місцева колоніальна адміністрація» ${ }^{10}$. «Вони чудово усвідомлюють, що їхнє утримання при владі, благополуччя і фізичне виживання можливе лише при умові подальшого збереження породженої російським колоніалізмом культурно-психологічної ситуації. Саме у цьому є розгадка штучного гальмування процесів українізації» ${ }^{11}$. «Речники неоколоніалізму переконують українців, що природна реакція народу на зовнішній тиск чи агресію - $є$ нічим іншим як негідним “зоологічним націоналізмом”, що опір русифікації - це екстремізм і розпалювання міжнаціональної ворожнечі, що вияв елементарної національної свідомості - це вже фашизм» ${ }^{12}$. Таким чином, українофобська гуманітарна політика стала важливою складовою формування клептократичного режиму в Україні.

Трансформаційні процеси в Україні, як і в Польщі, які відбувались протягом двох історичних періодів таких трансформацій (період дев'яностих років та сучасний період, що почався в двохтисячні роки), мають еволюційний характер. Протягом цих двох періодів як в Україні, так і в Польщі спостерігались різні вісі соціальних трансформацій. Для Польщі в дев'яностих роках головною домінантою була ліберальна вісь диференціації. Диференціація по вісі праві-ліві виводить на перший план дискусію з соціальних, економічних питань. В Україні також присутні ці головні вісі трансформаційних процесів. Проте, в різні історичні періоди вони мали різну, відмінну від ситуації в Польщі домінанту. В дев'яності роки спрямованість політичного процесу в Україні, як і в інших пострадянських країнах, характеризувалася двома ключовими тенденціями: стабілізацією та адаптацією. Як еліта, так і більша частина суспільства були зацікавлені в стабілізації суспільно-політичної ситуації після розпаду Радянського Союзу. Важливість адаптації полягала

10 A. Holâvka, Dolati spadsinu neokolonializmu, http://ntz.org.ua/?p=1574 (dostup: 5.05.2018).

11 Ibidem.

12 Ibidem. 
в тому, що переважна більшість суспільства була не готова до нових умов, тим більше до радикальних соціальних змін. Посткомуністична еліта також була не зацікавлена в змінах, оскільки намагалась зберегти владу. У двохтисячні роки починається новий етап трансформаційних перетворень в Україні. Особливостями цього періоду можна вважати нові тенденції, які з'явились в економічній, політичній, гуманітарній сфері суспільного життя України.

В економічній сфері домінантними стали три ключові тенденції. Поперше, в Україні, як і в Польщі у дев'яності роки, після економічного колапсу та дезінтеграції торгівельно-економічних та промислових зв'язків, почався процес економічного зростання. По-друге, в результаті економічного зростання та запровадження елементів ринку почав формуватися середній клас, малий і середній бізнес. По-третє, що є головним на відміну від Польщі, на період початку двохтисячних років у цілому завершився перерозподіл державної власності та економічних ресурсів країни між трьома регіональними кланово-олігархічними угрупуваннями: київським, дніпропетровським та донецьким, після чого між ними загострюється боротьба за перерозподіл цих ресурсів та влади. По-четверте, що суттєво відрізняє українську ситуацію від польської, в соціально-економічній сфері відбувалися разючі розшарування, коли „100 олігархів злиденної України володіють 90\% національного багатства країни - 54 млрд. доларів" ${ }^{\prime 3}$, у той час як понад 80 відсотків населення України живе за межею бідності ${ }^{14}$. Таке матеріальне розшарування суспільства висунуло запит на соціальну справедливість і сформувало соціально-економічне протиріччя як економічну передумову Помаранчевої революції. Реакцією ж олігархії на загострення соціально-економічних відносин стало закриття соціальних ліфтів і каналів вертикальної мобілізації суспільних верств населення. У такий спосіб розвиток соціально-економічного конфлікту сформував революційну ситуацію в країні.

Помаранчева революція стала першим значним запитом на демократію в Україні. На відміну від номенклатурної революції, це була революція цінностей. Ї̈і рушійною силою стало, в першу чергу, молоде громадянське суспільство, яке утворилось в умовах хоча й обмежених «олігархічною демократією», але все ж таки демократичних свобод. Іншу

13 M.A. Švajka, Oligarhične rozkradannâ bagatstv Ukraïni i pograbuvannâ narodu-zagroza iï nezaležnostì, irbis-nbuv.gov.ua/cgi-bin/irbis_nbuv/cgiirbis_64.exe? (dostup: 5.05.2018).

1480 vìdsotkiv naselennâ Ukraïni žive za mežêิ bidnostì - OON, www.radiosvoboda. org/a/26959841.html (dostup: 5.05.2018). 
складову революційної сили утворив затиснутий олігархами середній і малий бізнес та рештка київського олігархічного клану, який виявився обділений в результаті перерозподілу влади і власності. Така неоднорідна соціальна база революції не змогла висунути команду реформаторів та політичних лідерів, які втілили б ідеологічні гасла демократії та національного розвитку, що власне повторилося і після Революції гідності. Хоча тепер, під впливом останньої, а також російсько-української війни, населення не тільки західної та центральної, але й східної та південносхідної України підтримало ідеї національного відродження та європейський демократичний вибір ${ }^{15}$.

\section{Висновки для України 3 досвіду транформаційних процесів у Польщі}

Досвід поскомуністичного транзиту Польщі говорить про необхідність заміни таких компонентів політичної системи як: соціальна база, політична культура, політична еліта, опозиція, виборча система, політичні інститути влади, політична ідеологія, зовнішня підтримка.

Соціальна база. Формування соціальної бази демократії є ключовим завданням демократичних перетворень. Без масової підтримки з боку суспільства неможливі демократичні перетворення. Таку соціальну базу складає молоде покоління та освічені верстви населення, які не застали часів комуністичного режиму. Центральне місце у формуванні соціальної бази демократії займають інститути громадянського суспільства, незалежні 3МІ, асоціації малого та середнього бізнесу. Для становлення демократії потрібна критична маса внутрішніх акторів.

Особливість соціальної бази демократії в Україні полягає в тому, що вона має суттєві регіональні розбіжності. На Сході та Південному Сході України, де домінують споживацькі настрої, радянська політична культура з елементами кримінальної культури та колоніальні стереотипи поведінки, рівень політичної активності населення є дуже низьким.

Політичні еліти. Досвід Польщі доводить, що демократичні перетворення можливі при наявності консолідованої політичної еліти та об’єднанні опозиції в потужну дисципліновану організацію. Без

15 Ìdentifikaciâ naciï. Ukraïncì rozpovili pro svoï nacìoanl'nìst', movu, vìrospovìdannâ, ÊS ì NATO: https://tsn.ua/ukrayina/identifikaciya-naciyi-ukrayinciv-rozpovili-pro-svoyunacionalnist-movu-virospovidannya-yes-i-nato-947320.html (dostup: 5.05.2018). 
консолідованої еліти неможлива консолідована демократія. Саме завдяки утворенню консолідованої еліти були проведені демократичні перетворення в Польщі, в якої була чітка стратегія відновлення демократії та проведення економічних і політичних реформ. Так, демократичні перетворення в Польщі були здійснені завдяки поєднанню інтелектуальної та масової опозиції, об'єднаних сильною організацією, яку являв собою рух «Солідарність». Польський досвід також вказує на те, що частіше за все спільним консенсусом між старою владною елітою і опозицією є питання національної ідентичності. Це об'єднання зусиль різних за своїм ідеологічним спрямуванням партій заради нації. У польській еліті консенсус щодо національної ідентичності був досягнутий завдяки об'єднавчій ролі католицької церкви. Україна, на жаль, не може наслідувати цей приклад, оскільки в ній не сформована консолідована українська нація, тому питання національної ідентичності не є предметом консенсусу. Навпаки, воно стало предметом гострого національно-культурного конфлікту, який має тенденцію до ескалації.

Таким чином, в Україні відсутня не тільки консенсусна еліта, але й національна еліта взагалі. Втім, це не означає, що в Україні неможливо досягти консенсус. Перший раз він був досягнутий у 1991 році між націонал-комуністами і націонал-демократами з приводу отримання державного суверенітету України, що й визначило мирний характер «номенклатурної революції». Консенсус між регіональними елітами був досягнутий і в часи Помаранчевої революції, яка теж відбулася мирно. Проте, цей консенсус стосувався тільки права ренти на владу і власність у країні. Отже, в Україні владна еліта, як і контр-еліта, що знаходиться в опозиції, зорієнтовані не на національні інтереси, а на свою долю участі в рентній економіці та приватизації влади. Саме тому опозиційні партії формуються і об’єднуються не на підставі ідеології, а на основі бізнес-інтересів і політичних амбіцій їхніх лідерів. Відтак, партії в Україні $\epsilon$ надзвичайно персоналізовані. Вони створюються під конкретних персон для обслуговування їх приватних інтересів та інтересів їх близького оточення. Це $є$ однією з причин того, чому українська опозиція не здатна консолідуватись і консолідувати навколо себе широкі верстви населення.

Виборча система $\epsilon$ тільки механізмом представлення інтересів політичних сил, які ці інтереси намагаються просувати у владі. Тож, електоральна демократія ще не забезпечує консолідованої демократії. Услід за цим немає прямої кореляції між демократією та мажоритарною чи пропорційною системою. В Україні пропорційна система, яка вважається 
більш прогресивною, призвела до авторитаризму, а запровадження змішаної системи значно полегшило тотальний контроль правлячої Партії регіонів над місцевими органами влади. Якщо партії не дотримуються демократичних принципів під час виборів і під час діяльності в парламенті, вони сприяють формуванню авторитаризму. Якість парламенту визначається, насамперед, його представництвом: суспільством, політичними партіями, елітами. Головне, щоб виборча система була максимально прозорою, унеможливлювала фальсифікації, забезпечувала максимальну явку виборців і волевиявлення народу.

Зовнішня підтримка. Швидкий і мирний характер переходу Польщі від комуністичного авторитарного режиму до демократії був обумовлений, передусім, тим, що ці перетворення були безпосередньо пов'язані 3 європейською та євроатлантичною інтеграцією. Членство в НАТО забезпечило Польщі не тільки незворотній характер демократичних реформ, але й унеможливило повернення авторитаризму в посткомуністичний перехідний період. По-перше, приєднання до НАТО змусило владні еліти країн-кандидатів на членство прийняти умови та взяти на себе зобов'язання членства, пов'язані з утвердженням демократичних стандартів та сповідуванням демократичних цінностей. Тим елітам, які відповідали цим вимогам, надавалася всіляка підтримка з боку Альянсу. По-друге, і це головне, Альянс через свої механізми здійснював стримуючу функцію відносно монополізації трансфер-класами влади і власності в посткомуністичних країнах. Це пояснює той факт, що з одного боку, Польщу до НАТО та СС привели колишні комуністичні партійні функціонери, а з іншого - як приміром в Україні - ті трансфер-класи, які намагалися встановити авторитарний режим, чинили всілякий спротив європейській та євроатлантичній інтеграції і проводили в своїх країнах антинатовську та антизахідну пропаганду.

Процес приєднання до НАТО та СС дав Польщі можливість консолідувати еліти та широкі соціальні верстви населення. Сама ж ідея членства в НАТО та ЄС і стала предметом консолідації цих еліт. Україна втратила можливість такої зовнішньої підтримки демократичних процесів, принаймні на певний історичний період. Очевидно, НАТО та СС у процесі свого розширення враховували якісно іншу соціальну базу країн пострадянського простору. Завданням цих організацій була не інтеграція України 
в європейський цивілізаційний простір чи євроатлантичний безпековий простір, а недопущення відтворення нового радянського чи російського союзу, який мав би антизахідну спрямованість, тобто - повернення в Союз.

Україна мала шанс долучитися до НАТО, та еліта України залишається ще занадто сильно совєтизованою та колонізованою. Отже, потрібен певний історичний проміжок часу, протягом якого Україна має подолати тягар минулого радянського ладу і створити необхідні передумови для повернення в Свропу. Складність цього процесу не дає можливості копіювання чи перенесення західної моделі суспільства та політичного ладу на українське тло, як це було зроблено країнами Центральної Європи протягом дев'яностих та двохтисячних років.

Модель, яку потребує Україна, має враховувати цю їі історичну, ментальну і геополітичну специфіку. Відтак, перед Україною постають такі першочергові історичні завдання як: десовєтизація, деколонізація, дерусифікація, демократизація, деолігархізація, європеїзація та формування потужної інтелектуальної опозиції, досягнення консенсусу еліт щодо моделі майбутнього України та розробка чіткої стратегії суспільних змін.

Десовєтизація була необхідним, ключовим елементом в усіх без винятку трансформаційних процесах в країнах Центрально-Східної Європи. В країнах Вишеградської групи вона розглядалась як звільнення від радянської окупації і відсторонення комуністичних колаборціоністських партій від влади. В країнах Балтії десовєтизація сприймалась також як демонтаж окупаційного режиму і повернення до державного й суспільного устрою, який існував до 1939 року.

В Україні процес десовєтизації почався тільки зараз, після Революції гідності. Десовєтизація України повинна носити комплексний характер і охоплювати такі сфери як: система державного управління, законодавство, освіта, культура, інформаційна та гуманітарна сфери. Сфера державного управління в Україні до великої міри до цього часу залишається радянською. Тож, десовєтизація державних інститутів передбачає демонтаж рудиментів радянської системи державного та адміністративного устрою і їі заміну сучасною системою державного менеджменту. Вона також включає такі завдання як: адміністративна реформа, заміна старих радянських кадрів молодими та освіченими фахівцями, перехід на сучасну систему підготовки управлінських кадрів.

Законодавча база. В Україні продовжують діяти старі радянські закони, які зберігають та відтворюють радянську систему суспільних відносин. Відтак, десовєтизація законодавчої бази передбачає комплексну ревізію 
тих законів, які були прийняті ще в часи Радянського Союзу в сфері кримінального, цивільного, адміністративного, господарчого права.

У гуманітарній сфері десовєтизація передбачає: відмову від символів радянської комуністичної ідеології і перегляд історії Радянської України в контексті українських національних інтересів та традицій, подолання радянських міфів та стереотипів, споживацьких та патерналістських настроїв у суспільній свідомості. Особливої уваги потребує десовєтизація сфери освіти і культури, де все ще зберігаються та культивуються через російський шоу-бізнес, фільми, книги та журнали елементи радянської культурної традиції.

Деколонізація більшою мірою стосується процесів формування української нації та національної економіки. В економічній сфері вона покликана вирішити такі завдання: ліквідацію енергетичної залежності від Росії; інтеграцію української економіки в систему міжнародної промислової кооперації. У політичній сфері: формування національної еліти України на українських національних та європейських цінностях і традиціях; вихід 3-під впливу Росії, що передбачає обмеження цього політичного та економічного впливу на українських чиновників, політиків, владну еліту, державні структури, кадрову політику, суспільну думку та внутрішню ситуацію в Україні.

У гуманітарній сфері деколонізація означає, в перш чергу, дерусифікацію інформаційної сфери: радіо, телебачення, друкованих засобів масової інформації, Інтернету, освіти та культури. Мовна політика для забезпечення прав українців як титульної нації та прав національних меншин має орієнтуватись на пропорційне співвідношення етнічного складу населення в Україні. Іншим важливим завданням деколонізації гуманітарної та суспільної сфери є повернення російськомовних українців до української національної ідентичності, подолання в них «креольського» малоросійського комплексу меншовартості і формування патріотизму та відчуття гордості за Україну.

Деолігархізація. Цей процес буде відбуватися об'єктивно в силу соціальної та економічної контр-продуктивності цього паразитуючого політичного класу. Проте, в залежності від політичного режиму, він відбувається по-різному. Демократичні механізми позбавлення трансфер-класів права ренти на владу і власність полягають у відділенні бізнесу від політики. Ці механізми добре відпрацьовані в країнах із західними демократіями. Для України важливо запозичити та впровадити їх в українську практику. 
Свропеїзація передбачає широкий комплекс заходів по формуванню в українському суспільстві європейських демократичних цінностей, політичної культури та європейської культурної традиції, що в цілому передбачає встановлення та розвиток в Україні громадянського суспільства.

Досвід Польщі та ті кроки, які вона зробила на шляху демократизації, мають бути здійснені і в Україні. Очевидно, що сама Украйна має пройти друге коло трансформачій від авторитаризму і клептократії до демократії, якщо вона хоче залишитися незалежною суверенною державою $і$ зберегтись як повноцінна українська нація.

\section{Bìblìografîa}

80 vidsotkìv naselennâ Ukraïni žive za mežê̂ bìdnostì - OON, www.radiosvoboda.or$\mathrm{g} / \mathrm{a} / 26959841 . \mathrm{html}$.

Grabovs'kij S., „, Mi ukraïns 'kij narod: nacional'no-etnična mozaïka”. Etnonacional'nij portret Ukraïni, www.radiosvoboda.org/a/909004.html.

Holâvka A., Dolati spadŝinu neokolonialìmu, http://ntz.org.ua/?p=1574.

İdentifikaciâ naciï. Ukraïncì rozpovìli pro svoï nacìoanl'nìst', movu, vìrospovìdannâ, ÊS ì NATO: https://tsn.ua/ukrayina/identifikaciya-naciyi-ukrayinciv-rozpovili-pro-svoyu-n acionalnist-movu-virospovidannya-yes-i-nato-947320.html.

Kuczma L., Ukraina to nie Rosja, pereklad i adaptacîa Ê. Redlih, Platan, Kraków 2004.

Râbov A., Promežutočnye itogi i nekotorye osobennosti postsovetskih transformacij, http:// polit.ru/article/2010/08/12/riabov.

Soskìn O., Neokolonial'na zaležnist' Ukrä̈ni vìd Rosï̈: oznaki ta nebezpeka, http://national. org.ua/library/neokolonialna.html.

Švajka M.A., Oligarhične rozkradannâ bagatstv Ukraïni i pograbuvannâ narodu - zagroza iï nezaležnostì, irbis-nbuv.gov.ua/cgi-bin/irbis_nbuv/cgiirbis_64.exe?

Ugoda mìz Ukraïnoû ta Rosìjs'koû Federaciêû z pytan' perebuvannâ Čornomors'kogo flotu Rosìjs'koï Federaciï na teritoriï Ukraïni (ukr/ros), http://zakon5.rada.gov.ua/laws/ show/643_359. 